DOI: $10.17148 / I A R J S E T .2021 .8915$

\title{
ENVIRONMENTAL PROTECTION - CHALLENGES FOR INDIA
}

\author{
V. Preethi \\ Doctoral Scholar, School of Education, TNOU, Chennai 600015.
}

\begin{abstract}
This thematic paper deals with the environmental challenges of India and it initiatives to overcome these hurdles by way of enacting various legislations, administrativerules and regulations and formulating policies. The paper enumerates various aspects of challenges that India is facing. The sub themes are briefly discussed to throw light on the topic. It identifies the laws and policies since 1953, discusses NEP 2006, pin points the environmental degradation and impacts of human action. The global challenges of bio-diversity loss, global warming due to greenhouse gases, forest wild fires, sea eco-system, hazards of waste handling and managements, and other contributing factors are touched to present a bird's eye view over the posing challenges. The major challenges are biological and physical challenges. Biological challenges like extinction of animals, birds, flora and fauna cause damage to biodiversity. Physical challenges like Global warming, climate variation, floods etc cause extensive loss and damage to life and property. NEP 2006 has discussed various aspects of environmental degradation and warns against human activities undermining environmental protection. Population growth has led to scarcity of air, water, food and living space. Malnutrition savior diseases illleteratrcy, unemployment, poverty are its by-products. Disappearing of mangroves is causing pose marine life challenges and endangering sea ecosystem. Deforestation and mining are threats to the environment. Management and handling of waste of all kinds including e-waste must be strictly according to the laws. Environmental protection laws enacted by the international EPA and Government of India must be addressed fully and environmental justice must be established.
\end{abstract}

Key Words: Environment protection, Laws and Regulations, Biological and Physical challenges, Human Activities.

\section{INTRODUCTION:}

The problem of environmental degradation and pollution is as early as in the times of Plato 2500 years ago. Now the protection of environment is a matter of concern for all the countries irrespective of their size level of development and form of policy.The interaction of the society with nature is so extensive that we are all confronted with different kinds of environmental problems affecting the entire humanity. Human activity in some form or other is considered the main cause of environmental degradation.Hence, there is an urgent and indispensable need for the 'Environmental Protection' other vice deterioration of environment will deprive sustainability of all boon of natural wealth bestowed on the human kind by the nature itself.

Stephen Hawking declared "We are close to the tipping point where global warming becomes irreversible. ....actions could push the earth over the brink to become like Venus with a temperature of 250 degrees, and raining sulfuric acid."

India, the subcontinent, is one of the fast developing countries with its vast potential of both human and material resources. It is the second largest country with 1395 million of population. Of these nearly 400 million are living below poverty line (BPL) and 106 million are tribal living in forests. The population explosion of the country is hampering the development of the nation at every stage.The exuberant growth of urbanization, decline of cultivable land, water scarcity.

India, a land of multi lingual, diverse cultured with a long and sound heritage along with mystic superstitious beliefs and illiteracy faces severe environmental challenges. It is the duty of every citizen to fight against the odds along with the government and other local and global institutions for a better life at present and in future.

\section{MAJOR CHALLENGES:}

The major challenges that are faced by any community come from its own 'Biological activities' apart from the 'Physical aspects' of the nature. The human activities of urbanization, industrialization in the advent economic boon particularly after liberalization of trade and commerce with global gates wide open are causing greater environmental damages.

Consequently the Physical Challenges like 'Global Warming', Climate Variations', floods, droughts, earth quakes, tsunami, cyclones, hurricanes, etc; occur very often causing extensive lose damage to life and property very frequently. Increasingly there will be areas of the world, too hot, to live in as Greta Thunberg, the teenage climate warrior puts, "Our house is on fire. I want you to act as if the house was on fire, because it is." 
DOI: 10.17148/IARJSET.2021.8915

Any imbalance in any of the biological or physical constituents will have adverse effect on the ecological system of the universe. The global warming, caused by the greenhouse effect, is beginning its toll now.

To regulate human conduct, Governments and Global Institutions like UNO, INCEP, etc; have passed legislations and framed regulations. Law is an important tool to contain and eradicate crimes. Environmental Law is an important medium through which environmental degradation and pollution can be controlled and prevented. It involves the conservation of indigenous resources so that they can be used in a manner that is useful not only for the present society but also for future generations. It also governs interrelationship and inter dependency between natural resources and human beings. Major Challenges lie in the implementation of these laws and regulations. UNEP Report insists "to limit temperature increase to $1.5^{\circ} \mathrm{C}$, we must drop our greenhouse gas emissions $7.6 \%$ each year between 2020 and 2030 . This will take an all-hands-on-deck effort. Climate change, or global warming, is the greatest environmental threat we've ever faced. How we respond to this crisis will greatly impact both current and future generations and all other species." climate.gov makes it clear that $\mathrm{CO}_{2}$ has exceeded $410 \mathrm{ppm}$ in the atmosphere.

\section{ENVIRONMENTAL LAWS AND POLICIES OF INDIA:}

Under the Constitution of India various legislations have been passed by the act of parliament apart from adopting some British Laws on Environmental protection.

- Shore Nuisance ( Bombay and Calcutta) Act. 1853.

- The oriental Gas Company Act. 1857.

- The Indian Penal Code 1860.

- The Bengal Smoke Nuisance Act. 1905.

- The Bombay Smoke Nuisance Act. 1912.

- The Indian Forest Act. 1927.

- The Factories Act.1948.

- The Insecticides Act.1948.

- The Mines Act. 1952.

- The Prevention of Cruelty to Animals Act. 1960.

- The Atomic Energy Act.1962.

- The Water (Prevention and Control of Pollution) Act. 1974.

- Amendment of Article 48(A) Part IV, Article 51 A (g) of Constitution. 1976.

- The Air (Prevention and Control of Pollution) Act.1981.

- The Environment (Protection) Act. 1986.

- The Forest (Conservation) Act.1980 as amended in 1988

- The Public Liability Insurance Act. 1991.

- The National Environment Tribunal Act. 1995.

- The National Environment Appellate Authority Act. 1997.

- The Protection of Plant Varieties and Farmers' Rights Act.2000.

- The Wild Life (Protection) Act.1972 as amended in 2002

- The Biological Diversity Act. 2002.

- The National Environmental Policy. 2006

- Environmental Clearance Notification (EC) and

- Environmental Impact Assessment (EIA) 2006

- The National Green Tribunal Act. 2010

- Bio medical Waste Management \& Handling Rules 2015

- E-waste (Management \& Handling) Rules 2011 \& 2016

- Hazardous and Other Wastes Rules 2016 and many other acts, amendments and policies.

All the above acts, regulations and acts tend to regulate human activities causing [i] air pollution, [ii] water pollution, [iii]land and soil pollution, [iv]food pollution, [v]noise pollution and [vi]radioactive pollution by [a]indiscriminate use of water resources, [b]discharge of pollutants in air, [c]improper disposal of garbage and other human waste materials, [d]improper management of solid waste, [e]improper management of electromagnetic energy, [f]improper management of heat and sound and [g]failure in food protection. "The situation was worse between 1947 through 1995. According to the data collected and environmental assessments studied by World Bank experts India has made some of the fastest progress in addressing its environmental issues and improving its quality between 1995 and 2010"(Wikipedia). 


\section{THE NATIONAL ENVIRONMENT POLICY.2006:}

It was approved by the Cabinet on 18th May 2008 deals with Key Environmental Challenges, the causes and impact of the environmental degradation and pollution extensively. It also analyses the various ways and means of Environmental Protection. It enumerates various projects and action plans for the disposal and waste management. It lays emphasis on the cooperation among Individuals, Institutions, NGOs' Scholars, Researchers, Policy makers, Implementers, Field Workers and others concerned [ie; every citizen] The NEP stresses the need for Environment Education for the lay man and to children, who hold the future of the nation. It shows the way to the Poverty as a cause for Environmental Degradation.

The NEP 2006 declares that "The key environmental challenges that the country faces relate to the nexus of environmental degradation with poverty in its many dimensions, and economic growth. These challenges are intrinsically connected with the state of environmental resources such as land, water, air and their flora and fauna. The proximate drivers of environmental degradation are population growth, inappropriate technology, and consumption choices, and poverty, leading to changes in relation between people and ecosystem and development activities such as intensive agriculture, polluting industry, and unplanned urbanization."

The NEP 2006 while discussing causal factors identifies poverty as "a major factor in enhancing and perpetuating poverty, particularly among the rural poor. The degradation impacts soil fertility, quantity and quality of water, air quality, forests, wildlife and fisheries. The dependence of the rural poor, in particular the tribal societies, on their natural resources, especially biodiversity, is self-evident."

The NEP 2006 warns that "the poor are more vulnerable to the loss of resilience, the capacity of an ecosystem to recover from shocks and surprises, whether manmade or natural, in ecosystem." Reduction in the resilience may cause distress and the people being made destitute

The urban poor suffer the environmental degradation caused by the inappropriate or the lake of poor sanitation and waste disposal, related to polluted industrial and transport waste. This skeptically affects the quality of air, water and soil and hence it tells upon in the health of urban poor. The environmental degradation poses great challenges that affect their capability to seek and retain employment, attends school, and enhances gender inequalities. Poverty, gender in equalities,population growth and environmental degradation mutually reinforce each other. Thus poverty, whether rural or urban remains a Challenge to Environmental Protection in the Indian context.Economic growth in the post liberalization is slowly reducing poverty.

\section{POPULATION GROWTH AND ENVIRONMENTAL DEGRADATION:}

Population is seen as one of the biological cause for the Environmental Degradation. It was already mentioned that Poverty and population mutually reinforce each other. The world's population is estimated as 7.5 billion in the middle of 2021 and projected to be 7.82 billion and 9.04 billion in the year 2025 and 2050 respectively. In India alone the population was 1033 million in 2001, 1225 million in 2011, and is1395 in 2021, it is projected as 1443.54 million and 1628 million in 2025 and 2050 respectively. If the population continues at this rate, its impact on environment could be devastating.

Natural resources dwindle reducing per capita availability of air, water, nutritious food [even meager food at least, in many cases], living place, health care, sanitation and clean energy to each individual. On the other hand the amount of biological waste output is enormous that needs greater attention and effort to dispose them properly. Air, water and soil get contaminated. Slums, the congested dwelling place, without proper civic amenities breed diseases and induce the incidence of a number of critical health problems. These health problems drain the manpower and reduce manpower output considerably resulting in heavy financial lose, inefficiency and Environmental degradation.

Malnutrition, a global concern, plays a major havoc in the human life. Malnutrition is mainly caused by the uneven distribution of food triggered by the ever growing demand. It also leads to different diseases. Climate save movement.org in its article titled - we face a climate emergency claims "Disease vectors are spreading with rising temperatures. Ecological and agricultural systems could break down and possibly lead to mass starvation. Methane comes from cows, and is 70 times more damaging than carbon dioxide emissions. Nitrous oxide emissions arise from the huge amounts of fertilizer used to grow the genetically engineered corn and soy which are fed to animals raised in concentrated animal feeding operations (CAFOs). Nitrous oxide pollution is even worse than methane-200 times more damaging per ton than carbon dioxide." In 2018, The UN Intergovernmental Panel on Climate Change (IPCC) stated that "we have 12 years left to make major dietary changes."

According to World Watch Institute, "animal agriculture generates $51 \%$ of greenhouse gas emissions. Nearly $80 \%$ of agricultural land is used for animal feed and grazing. The Earth is in the midst of the sixth mass extinction of life. Scientists estimate that 150-200 species of plant, insect, bird and mammal become extinct every 24 hours."

Deforestation is another global concern. But this is a major challenge for the developing country like India. With population explosion clearing of several square kilometers of forest land for housing and industries schemes result in 


\section{DOI: 10.17148/IARJSET.2021.8915}

the destruction of great variety of organisms. This destruction paves way for the disruption of the entire food chain and ultimately the eco system.

In short, population explosion has an adverse effect on the environment. Human basic needs such as food, clothing, housing, medicines etc; are derived from the environment. The immense interaction between nature and humankind is causing serious damage to the environment. It is the responsibility of every citizen of the world to recognize positive relationship and mutualism.

\section{IMPACT OF HUMAN ACTIVITIES ON ENVIRONMENT:}

Human activities like migration from rural environment to urban environment are increasing alarmingly. People of the developing countries prefer to live in towns and cities rather than in villages for various reasons such as better civic amenities, better education, better employment opportunities, entertainment and luxuries. The trend of this migration may continue, according to Sociologists, for another 50 to 100 years in the future. An estimated 285 million lived in urban areas according to 2001 Census. Now in 2021488 million (35\%) of the nation's population is living cities. States like Tamil Nadu and Maharashtra, the percentage of urban dwellers is high with 43.86 and 42.40 respectively. Gujarat has 37.35\%, Karnataka and Punjab 33.9\%. Maharashtra has 41 million are living towns and cities. This migration results in unplanned urbanization paves way for degradation of environment in three ways: i) The transformation of natural habitation to human habitation of urban built areas (Concrete Jungles), ii) Unplanned exploitation of resources available naturally. iii) wastes produced and disposed in the atmosphere, hydrosphere and lithosphere of the earth. This challenge needs to look into it deeply. Urbanization alters the atmosphere adversely.

The temperature of the atmosphere, that is the air with all its gases, increases considerably because of the large number of the people, lack of green cover proportionally, release of significant amount of heat energy and gases by the vehicles and industries. Polluted air is the major challenge of the urban areas. The world's biggest challenge is air pollution. The report of World Health Organization (WHO) 2019 declares that " 9 out of 10 people breathe polluted air. It further reveals that 4.2 million people die every year due to outdoor air pollution. Industrial sources and motor vehicles remain the major pollution contributors."

"Close to 1 million animal and plant species face extinction," according to a UN report, "making it one of the top environmental concerns this year and beyond. Indeed, biodiversity is experiencing an existential threat at a perilous rate." Forest fires are raging in different regions of the world.

Hydrosphere is largely affected by the concrete roads and congested buildings rain water runs off causing severe flooding. Mumbai's flooding paralyzed life for more than 24 hrs.in July 2005 and 2021. Water often quickly drains from streets into storm sewers instead of infiltrating into soil as in natural environment. Hence there is acute water scarcity and greater demand. Surface and ground water pollution is produced by urbanization. Discarding of waste into the water is common as they dilute and disperse pollutants, beyond its capacity. Industries like tanneries, metal plating operations, pulp mills, refineries, breweries, chemical plants etc; contribute much pollutant such as dioxins, pesticides grease, oil acids, heavy metals, and noxious gases to the environment. Urban areas produce significant amount of raw sewage. It is a source of nutrients that can lead to eutrophication of lakes. Eutrophication is a condition in an ecosystem where high nutrient concentration stimulates blooms algae. This reduces the dissolved oxygen content of water. At one stage for want of oxygen and nutrients all organisms die out. Sewage water contain hepatitis virus, cholera bacterium pathogens etc.

Lithosphere, the upper surface of the earth, has been urbanized irreversibly to the extent of $1 \%$ of the Earth's total terrestrial surface. The conversion has resulted in complete alteration in the physical and biotic character of the Earth's land surface.Urbanization has left another impact on plants, animals and loss of habitat. This results pollution, destruction and alteration in local climate. Habitat loss can cause in some native species to become endangered and extinct.

The environmental problems of Rural India are in no way better than that of Urban India. Lack of basic amenities such as healthy sanitation, clean and safe drinking water, planned habitats, separate living places for humans and animals, literacy and education, safe livestock, health and medical facility is hampering rural life. There is no proper mechanism for the safe disposal of community waste. The contamination of water bodies creates unhygienic living conditions. Lack of food, water and employment drives them to exploit the available natural resources like forest produce, livestock, poultry, and land. Poverty, as discussed earlier, is one more factor for the Environmental degradation.

Human activities can be changed provided there is a change in attitude in every stage of the life. India lives in villages. The challenge of Environmental Protection is not an easy job in a country like India where people have strong belief in fate and superstitions. Only literacy and proper education can bring the physical and other challenges.

There are many other challenges out of emerging global environmental concerns. They are climate change, stratospheric ozone depletion and biodiversity loss. Again, the problems, causes, and the impacts are all chain reactions of the human approach towards the nature and its resources. Not an act of human behavior is safe and isolated that cause adverse effect of environment. Global warming is on the rise and is causing irreversible and irrevocable damages in the environment. 


\section{GLOBAL WARMING AND GREENHOUSE GASES:}

The phenomenon of global increase in temperature is called 'Global Warming'. Greenhouse gases are largely responsible for global warming. These may have catastrophic consequences for life on earth. Greenhouse gases are: [i] Nitrous oxide ( $\left.\mathrm{N}_{2} \mathrm{O}\right)$, [ii] Methane $\left(\mathrm{CH}_{4}\right)$, [iii] Carbon dioxide $\left(\mathrm{CO}_{2}\right)$, [iv]Hydro fluorocarbons (HFCs), Sulphur hexafluoride $\left(\mathrm{SF}_{6}\right)$ and Per fluorocarbons (PFCs) and some 25 other gases all have been spewed into the atmosphere in large amounts largely as a consequence of industrialization and human activities such as burning of fossil fuels, clearing of lands, and agriculture. Each greenhouse gas absorbs radiation at different wavelength, so they vary in their potency. Measurements indicate that concentration of several greenhouse gases in the atmosphere have increased. It is estimated human activities contribute about six billion tons of carbon dioxide $\left(\mathrm{CO}_{2}\right)$ to the atmosphere each year. About half of this amount is taken up by natural processes into the oceans and land ecosystems.

The presence of large amount of carbon dioxide causes imbalance in the infrared radiation and there by heats the Earth's surface, and is called 'Global Warming'.

Global warming causes climatic changes. In turn Climatic changes causes floods, droughts, earth quakes, cyclones, depressions, erratic monsoons, typhoons, tornadoes, melting of glaciers and a host of environmental problems. The developed countries are trying to contain global warming and have understood the need for technocratic solutions to the challenge of global warming. A total of 141 countries, both developed and developing, have committed to reduce emission of greenhouse gases substantially between the years 2008 and 2012. This international agreement was negotiated in 1997. The Agreement is called KYOTO PROCOL. India is one among them.

\section{CLIMATIC CHANGES - IMPACT ON ENVIRONMENT AND SOCIETY:}

India is highly sensitive to climatic changes. The country faces more erratic monsoon patterns, more floods and droughts and steadily shrinking water tables, melting Himalayan glaciers. India.

According to the World Bank, India's carbon dioxide emission has increased by 88 percent since 1990. The annual coal consumption in India has tripled since 1980. Coal burning is one of the sources of carbon dioxide emission. However the per capita carbon dioxide emissions are relatively low. The average Indian is responsible for six percent of the $\mathrm{CO}_{2}$ emitted by the average citizen from the United State.

The temperatures are rising and that weather patterns throughout the globe are being disrupted as a consequence. The changing climate poses the greatest challenge facing humanity to day, and nations must find away to work with each other equitably and quicklythe desired attitude towards Environmental Protection. According to the National Oceanic and Atmospheric Administration (NOAA) Global Climate Summary, "annual temperatures have surged at an average rate of $0.08^{\circ} \mathrm{C}$ per decade since 1880 and over twice that rate $\left(+0.18^{\circ} \mathrm{C}\right)$ since 1981 . This rise brought about extreme weather events in 2020, including unprecedented bushfires in Australia, locust invasion in several African countries, a record-breaking heatwave in Antarctica where temperatures rose above $20^{\circ} \mathrm{C}$ for the first time, crazy wildfires in California, among others."

\section{CLIMATE CHANGE, MONSOON, FLOODS, DROUGHTS AND ENVIRONMENT:}

Climate Changes are very frequent now-a-days. The greenhouse effect is causing erratic climatic conditions throughout the world. India is no exception from this state of affairs. On July 26, 2005 and in July 2021 Mumbai faced the unusually heavy downpour. Heavy rains poured in Mumbai. The city came to stand still for days together. Almost all the major highways were flooded knee deep, 6.4 million Railway-commuters rendered helpless. The financial capital's airport was flooded and was closed. The people were subjected to immense hardship. Not only Mumbai suffered such a disaster but also Bengaluru and Chennai too suffered floods.

Urban floods though caused by the climatic changes, causes much damages due to poor planning and short term opportunistic decisions. Such visionless decisions destroy natural environmental safeguards and neglect the needs of the city residents. Floods of Patna in nineteen eighties had caused extensive damage to lives. Nearly ten thousand people lost their lives. Andhra Pradesh, Orissa, West Bengal and some North Eastern states like Assam, Tripura are some of the states which are regularly affected by cyclones and floods almost every season.

The floods of Rivers Ganges, Brahmaputra, Mahanadi are so notorious that they cause heavy lose to life and property every year. Millions of people are displaced. Scores of diseases affect the poor and displaced. Scarcity of potable (drinking) water is another problem as the floods contaminate all the sources. Epidemics crop up challenging sanitation and health initiative and execution of relief works. Floods erode soil resulting decline in agricultural activities and loss of produce and revenue. On average, floods affect about 5,000 square kilometers of land and4.5 million people in India each year. 
DROUGHTS:

Climate change can cause water shortage especially during the dry seasons. India already struggles with acute water scarcity. The country has $16 \%$ of world's population, but only four percent of its water resources. The per capita water availability water is so low that any drought would upset the entire community and the environment thereby. Artificial scarcity of water, due to various political reasons, may also cause droughts in the southern regions of India. Cauvery River dispute is the best example of political fight-outs between Tamil Nadu and Karnataka, Mullaiperiyardam dispute between Tamil Nadu and Kerala apart from some minor disputes between Andhra Pradesh and Tamil Nadu over years. The extending desert area of 'Tar Desert' and formation of new deserts may also pose extensive environmental problems. Dwindling water resources due to the climatic changes are the real threats to the Environment.

\section{DISAPPEARING MANGROVES - ENVIRONMENTAL CONCERN:}

Mangroves are complex plant with salt tolerances found in tropical inner tidal coastline areas and they live in communities. They are self-propagating and, if undisturbed, will grow quite easily where the soil and locations are conducive.

Mangrove ecosystem plays a crucial role in protecting the coastline during natural disasters. They shield against the destructive hurricanes and cyclones. as well as encroachment by the sea and check soil erosion and stabilize the shoreline. They promote sustainable fisheries and serve as the home of a wide range of flora and fauna including crocodiles and tigers. Mangrove supply nutrient inputs and act as main source of energy for tropical estuaries. Biomass productivity of mangroves is relatively high and they act as reservoir in assimilation of wastes. They also have an economic significance. They provide a wide variety of goods and services such as durable timbers, fuel wood of high calorific value, protein rich fodder for cattle, edible fruits and vegetables and traditional medicine.

Thick mangroves are natural barriers protecting the coastline and land from the fury of hurricanes and cyclones. 'Sundarbans', at the mouth of the River Ganges, the world's largest mangroves, is the home of 'Bengal Tigers'. Destruction of Sundarbans and its thick mangrove vegetation it makes the Gangian Delta more endangered. The raising tides may sink Small islands and reduce living space of the Bengal Tiger and other species.

Mangroves saved life and property during the 'Super Cyclone' which devastated Orissa in 1999/2000. The 'Tsunami' of December 26, 2004 hit the coasts of Tamil Nadu and Andaman and Nicobar islands apart from south eastern countries. The damage and devastation were minimal in places with thick mangroves than the places without them. The survival of mangrove is threatened by felling, grazing, reclamation, urban development, industrializations and mining.

\section{COASTAL AREAS - SEA-ECOSYSTEM AND ENVIRONMENT:}

Coast is the meeting ground of land and water. Coastal environment constitute a critical national and global resource that suffers widespread degradation due to human impact. The topographical features are less contrasting than the interior regions of land masses, but they are endowed with rich renewable resources, accessibility and a communication network.

To-day $50 \%$ (about 3.2 billion) of the world's population live along the coastline spread over 80 percent of the world's 218 sovereign states. India has $5,422 \mathrm{~km}$ long coastline apart from nearly $2300 \mathrm{~km}$ of island coasts. Within $50 \mathrm{~km}$ from Indian coast approximately 250 million people live .

There are four important characteristics of Costal Area Environment (CAE), and makes it a specially sensitive ecozone. First,

1) The CAE- I is called 'interface zone' meaning the land and sea meet. It is therefore dynamic and non-static in its geo-physical and chemical parameters. This zone is active as the waves continue its geo-physical and chemical activities.

2) The CAE- II, the productivity of the zone is extreme on the planet.

3) The CAE- III, it is the last zone and highly polluted.

4) The CAE- IV This zone inhabitates fishermen.

Till recently, the coastal areas were the home of fishing communities. But, now the coasts have a wide range activities that include stared hotels, resorts, missile launching facilities, sea cargo terminals, aquaculture farms, ship breaking yards, large chemical industry units, nuclear power plants refinery units, pilgrimage centers, fishing harbors, coastal high ways, amusement parks, luxury residential colonies, and what not?.

Since it is tail end eco system, the amount of pollution from the upstream industries and landward societies is so enormous that the CAE needs greater attention than it is receiving now. Most of the development takes place in violation of existing laws particularly the Coastal Regulation Zone (CRZ) norms. One 'Tsunami' (on 26.12.2004) tragedy exposed the shortsightedness of our policies that disregarded the importance of natural environmental safeguards. 


\section{DAMS, WATER BODIES AND ENVIRONMENT:}

The report of the 'World Commission on Dam' was released by Nelson Mandela in November 2000. It recommends smaller dams instead of large and big ones. Building larger and big dams involve social and environmental aspects. Displacement of large number of people from their natural habitat, lively-hood, and their rehabilitation are the social aspects whereas deforestation is the main environmental aspect.

The efficacy of large dams is in question. The WCD 2000 gives substantial evidence about the problems that are created by dams exceeding a certain size. India has the largest number of big dams under construction in the world. India has rejected the WCD 2000 report despite of its active participation. India's argument in support of big dams is to create 200 billion cubic meters of storage in next 25 years for power generation and irrigation. It is anticipated to generate at least $40 \%$ of the requirement 158,228 MW in 2031-32 from hydropower projects. This would mean: Displacement of at least 0.67 million people each year, total of $16.67 \mathrm{~m}$ people over the 25 years and Submergence of about 100,000 ha of land each year, including 40,000 ha forest land. India has the largest irrigation infrastructure in the world but performs far below its potential.

Controversy surrounds the dam projects that have been constructed, the Indira Sagar in Madhya Pradesh and the Tehri Dam in Utteranchal. The lack of a proper Resettlement and Rehabilitation package for those affected by the Indira Sagar project has led to much suffering. Tehri dam is a massive $260.5 \mathrm{~m}$ structure. It is highest rock fill dam in the world. It is located in the seismically active central Himalayan region. It is designed to withstand earthquakes of magnitude up to 7.2 on Richter scale - about the magnitude of the 2005 Kashmir earthquake. Tehri dam is the project where the social and environmental impacts of the dam have been sacrificed. It is alleged that officials have misrepresented facts and misled the courts with regard to 'Environmental Impact Assessment' (MIA). If the dam was to bust unfortunately, Rishikesh and Hardwar could be wiped out in a few hours and Millions of people living as far south as Bulandshahar could be threatened with submergence. Landslides are major threats to the dam. A huge wave caused by a major landslide could overtop the dam resulting in massive damages in downstream. Seismic loading due to the mass of the reservoir water can increase the risk posed by the dam.

The Government of India has sanctioned four large and mega dam projects to be built in the Himalayan state of Arunchal Pradesh. This mountainous state will meet most of the power requirement of the nation on completion. The government has not taken the threat it poses to Environment in to account. The fragile Himalayan eco-system is recognized as a global biodiversity hotspot. It has a dozen National Parks and Wildlife Sanctuaries created to protect the flora and fauna. There are other options to large dams, such as rain water harvesting, ground water, watershed development, minor irrigation projects, improving the performance of existing infrastructure etc.,

\section{FORESTS AND WILDLIFE:}

The National Environmental Policy speaks about "recharging of mountain aquifers which sustain our rivers. They, as the policy claim, conserve soil, prevent floods and droughts and provide habitat for wildlife and the ecological conditions for maintenance and natural evolution of genetic diversity of flora and fauna. They also yield many forest produce."

The NEP, on the other hand acknowledges, the significant loss of forest cover. It also enumerates the causes of loss both direct and indirect. The direct reasons are conversion of forest lands to agriculture, settlements, infrastructure and industry. The indirect causes are commercial extraction of fuel wood, illegal felling and grazing of cattle. It is pathetic that the government is indifferent towards the illegal exploiters of the wealth. More over the government itself is exploiting the resources unmindful of damages to the environment.

The best examples for the government's gross negligence of environmental concerns are the sanction of large and mega dams even after WCD's clear proofs, that too in the fragile Himalayan Mountains with seismically active regions. The region also houses many National parks, wildlife sanctuaries, biomass etc. The government turns a blind eye on the conversion of farm lands into concrete jungal. The state of the wildlife conservation is no good. Illegal poaching of reserve animals goes unchecked. The endangered species are not protected. Commercial exploitations of wildlife are not punished accordingly. The encroachment of forest land is unchecked but at the same time the tribal dwellers are denied their rights.

\section{MINING AND ENVIRONMENT:}

Barren land, disrupted ground water table, polluted rivers are some of the problems caused by mining. Mining destroy fields and degrade the habitat of ordinary people. Unscrupulous mining poses greater health hazards mainly cause pulmonary diseases. Noise pollution is another major problem. Mining is causing irreversible environmental degradation. An increasing number of environmental controversies around the country centre on mining. There has been displacement of local communities. An estimated two million people have been displaced by development projects in Orissa alone. 


\section{DOI: 10.17148/IARJSET.2021.8915}

Mining projects are sanctioned, unscrupulously without any norms, in the pretext of development. Nothing is taken into consideration either to protect the environment or the affected people. The government simply cold shoulders the protesters. There are many illegalities in sanctioning of projects. The best example is that of Sterllite Bauxite Mining Company. The Empowered Committee of Supreme Court has found illegality in central government clearances to Sterllite Industries' bauxite mining project in Orissa diverting forestland for the project. Dumping of mining waste is another problem. The rubbish blocks waterways and cause blockage of rainwater seepage channels and affect ground water level.

\section{ENERGY AND ENVIRONMENT:}

Energy needs of the country are enormous. With ever growing population and expanding industrial base the demand for energy is growing many folds. The production of safe energy is a distant dream. Any form of energy production be it hydro power, thermal or nuclear involves environmental problems.

Coal, firewood, and oils are traditional components of energy. They emit CO2, N2O, SO2, and other harmful gases while burning and spoil the atmosphere. Electricity is seen as clean energy source. But, there are many environmental problems. For production of hydro power water is to be stored in dams. Dams in turn cause ecological and social problems. Thermal power production requires large amount fuel. Coal, furnace oil and other combustible materials produce solid and gaseous waste. Nuclear power production involves radiation hazards, which affects people for generations.

\section{ENVIRONMENTAL HAZARDS:}

Almost all the human activities pose challenges to Environment. Industrialization, displacement of local people, nuclear waste, conversion of farm and forest lands, mining activities, consumption of natural resources in excess, discharging solid and fluid effluents, chemical wastes, motorization, are a few of them. They also cause 'acid rains', genetic modification in living organism, low ground water table, dwindling of natural resources and health related problems. It is the duty of every citizen to protect the environment apart from the government which is toothed with various laws, acts, and regulations

\section{WASTE MANAGEMENT AND ENVIRONMENT:}

Wastes - solid wastes and fluid wastes (liquids and gases) pose the greatest challenge to the environment. Waste management is the need of the hour. Re-cycling, re-using, safe disposal, burying, burning and reducing are some of the methods of disposal of the wastes. The disposal of hazardous wastes like asbestos, nuclear remains, and burgeoning electronic industry needs greater attention. Apart from locally generated wastes within India by industries, there are many industries which import wastes for recycling and there are ship breaking yards, which add to the woes.

International environmental safety laws have been in existence. 'Basel Convention on the control of Transboundary Movement of Hazardous Wastes and their Disposal (1992)'.has clearly laid down guidelines for the disposal of hazardous wastes. But violations continued to be the norms rather than exceptions in the ship breaking yard of Alang, Gujarat, despite existing guidelines and pollution control boards, environmental safety is not a priority in many waste disposal exercises.

Common Effluent Treatment Plants (CETP) is used for liquid waste disposal. Though the CETP have existed for almost a decade in several large industrial estates in the country but their efficiency is still a question of debate. With growing computerization, the quantity of e- waste is also increasing rapidly. Millions of Cell phones, TVs, Calculators, and other electronic goods find their way to the dustbin within short period of usage. The waste contains plastics, silica, and metals like lead, aluminum, iron, tin, copper and a few rare elements. A single computer may contain over 50 highly toxic metals and compounds. There is an urgent for regulation of this e-waste disposal. Northern and western countries dispose their used up e-goods to countries like India, China, and some other southern countries.

\section{THE STATUS OF ENVIRONMENTAL PROTECTION LAWS AND REGULATIONS:}

The Environment (Prevention) Act, 1986 (EPA) gives power to the central government of Environment and Forests to take all measures that it feels is necessary to protect and improve the quality of the environment and prevent and to control environmental pollution. To meet this objective the Central Government can restrict areas in which any industries, operation or processes or class of industries, operations or processes shall not be carried out or shall be carried out subject to certain safeguards. The law also gives power to prohibit or restrict the location of industries and carrying on certain operations or processes on the basis of considerations like the biological diversity of an area, maximum allowable limits of concentration of pollution for an area, environmentally compatible land use, and proximity to protected areas. Since then the EPA has been used in various cases. Since 1980's the government has identified various regions of environ - mental importance and classified them accordingly. Some of them are: ESA Ecologically Sensitive Area. , EFA - Ecologically Fragile Area. , CRZ - Coastal Regulation Zone. , CAE - Coastal Area Ecosystem. , BR - Biosphere Reserve. ,etc 


\title{
International Advanced Research Journal in Science, Engineering and Technology
}

\author{
Vol. 8, Issue 9, September 2021
}

DOI: 10.17148/IARJSET.2021.8915

Any project that may affect the ecosystem needs to be assessed. The EPA 1986 insists on notification of the project in public and provides opportunity for Public Hearing. The Environment Impact Assessment (EIA) committee should certify the project as 'Clean Project' without any detrimental factors or they have taken proper care of such Environmental Threats.

\section{CONCLUSION:}

The implementation of these acts, rules and regulations needs constant monitoring. But in reality, there is little monitoring on the status of most of these notifications. Public hearings are not held at all in many cases. Even if it is held, it would be only a stage managed show. The government floats many of the norms in the name of globalization and economic liberalization.

Despite all these difficulties, the significant aspect is that legal backing for conservation exists. The role of every citizen and committed NGO's as catalysts in this process is critical. The Governments both at the centre and the states indulge in diluting the laws in the name of economic, prosperity, creation of job market apart from certain political commitments. There must be transparency in granting and clearing projects adhering strict environmental rules and regulations. The Government must promote environmental justice. Environmental protection should be a peoples' movement. The more widely, the ESA concept is understood, the more likely it will be used. Its recognition as an important tool for securing conservation of natural resources and people's livelihood will then follow.

Let us join together to dedicate ourselves for a clean tomorrow.

\section{REFERENCE:}

1. Anubhakaushik and kaushik C. P. (2006), perspectives in environmental studies. Isbn: 81-2241755-8. New age international publishers.

2. Anupamchakravartty, (2015) six ebviromental laws to be amended soon, https://www.downtoearth.org.in/news/governance/sixenvironmental-laws-to-be-amended-soon-49317.

3. British broadcasting corpration, mumbai rains, https://www.bbc.com/news/world-asia-india-57938839 mumbai rains.

4. Chetan chaun, 2021, hindustan times, on world environment day, india's top ten concerns, https://hisdustantimes.com/india-news/on-word environment-day-india-s-top-ten-concerns-101622810777515.html.

5. Debashree sen, information about the forest ecosystem, https://sciencing.com/types-primary-consumers-coniferous-forest-8646063.html.

6. Government of india, ministry of environment, forest and climate change, central pollution control board https://cpcb.nic.in/.

7. Government of india, ministry of tribal affairs, annual report 2020-2021, https://tribal.nic.in/downloads/statistics/annualreport/arenglish2021.pdf.

8. Nagarajan. K., sivakumar. P., nithyasri. N., and srinivasan. R. (2005) environmental education. Ram publishers.

9. Manorama year book 2020, isbn 978-81-942299-9-5.malayala publication

10. Rebecca lindsey and luann dahiman, 2021, climate change: global temperature, https://www.climate.gov/news-features/understandingclimate/climate-change-global-temperature.

11. simon elstad, 2021, 7 critical environmental concerns for 2021, https://greenerideal.com/news/environment/top-environmental-concerns/.

12. Tavinder sindhu, shreyansh rathi, 2021, india environment and climate change laws and regulations. Https://iclg.com/practice-areas/environmentand-climate-change-laws-and-regulations/india.

13. Tejangchakma, dr. Martemjenthe, Indigenous world 2020: india 2020, https://www.iwgia.org/en/india/3601-iw-2020-india.html.

14. Vinay vaish, hitender mehta (2017), india: environmental laws in india https://www.mondaq.com/india/waste-management/624836/environment-laws-in-india.

15. Wikipedia, https://en.wikipedia.org/environmental issues in india.

16.https://en.wikipedia.org/wiki/environmental_policy_of_india. 